\title{
BOTE CENTRAL: CREATING A CHAIN OF HAPPINESS FOR PHILIPPINE COFFEE FARMERS
}

\author{
Raymund B. Habaradas* \\ De La Salle University, Philippines \\ Ian Benedict R. Mia \\ De La Salle University, Philippines
}

\begin{abstract}
The Philippine coffee industry is beset by a multitude of problems: declining land area planted to coffee, poor quality of coffee beans due to poor farm practices, and low productivity of coffee farmers who are unable to earn enough commensurate to their hard labor. As a result, Philippine coffee bean production has been on a decline for over a decade, in spite of the increasing local demand for coffee. In this paper, we illustrate how the different challenges faced by the Philippine coffee industry are closely interlinked, but are inadequately addressed by the fragmented efforts undertaken by government and the private sector. Utilizing a single-case (embedded) study research design, we demonstrate that a holistic and collaborative approach that targets critical leverage points in the coffee supply chain might be a viable approach to address the systemic nature of the problem. The case of Bote Central, particularly its Kape't Buhay Program, highlights the importance of having a mechanism that effectively coordinates the efforts of the various players in the coffee supply chain towards a clear and compelling goal.
\end{abstract}

Keywords: Bote Central, Philippine Coffee Alliance, Coffee Industry, Inclusive Supply Chain.

Received: 4 October 2020

Accepted: 19 April 2021

https://doi.org/10.33736/ijbs.3769.2021

\section{INTRODUCTION}

The Philippines has become a coffee-drinking nation. For many Filipinos who have been "addicted" to coffee and must have their daily dose of caffeine, "coffee is life." But this does not seem to be the case for many coffee farmers in the country, who are unable to raise their quality of life due to the low income they get out of selling coffee beans. The situation is markedly worse for coffee farmers based in the uplands, who are forced to sell their produce to middlemen, often at very low prices. Among the players in the entire coffee supply chain, it is the farmers who are unable to capture sufficient value commensurate to their hard labor.

It is not a surprise, therefore, that in spite of the increasing demand for coffee products in the Philippines, local green coffee bean production has declined by an average of 3.51 percent per annum over a ten-year period from 52,047 tons in 2006 to 36,171 tons in 2015, and has to be augmented by imports.

\footnotetext{
* Corresponding author: Raymund B. Habaradas, De La Salle University, 2401 Taft Avenue, Manila, Philippines; Telephone: +639178347442; Email: raymund.habaradas@dlsu.edu.ph.
} 
In 2015, the Philippines' Department of Trade Industry (DTI) reiterated in a report how the country is a major importer of coffee, and is bound to become one of the top five global consumers of coffee by 2021 (DTI, 2017). The country's imports increased from US\$69 million in 2007 to US\$262 million in 2014. In contrast, the country's exports of green and roasted coffee beans accounted for less than $0.0004 \%$ and $0.0003 \%$, respectively, of global trade. Among the reasons that have contributed to this situation are the following: (a) declining hectarage planted to coffee; (b) poor quality of coffee beans due to poor farm practices; and (c) low productivity of coffee farmers. Clearly, work needs to be done not only to increase local production and enhance export capabilities, but also to ensure that the productivity and overall well-being of Filipino coffee farmers are placed front and center.

Efforts of the Philippine government over the years had been found wanting, prompting a group of concerned stakeholders, known as the Philippine Coffee Alliance (PCAi), to take the cudgels for the marginalized coffee farmers. Playing an important role in this alliance is Bote Central, a social enterprise led by couple Basilio and Vie Reyes, who first envisioned a "chain of happiness" for Filipino coffee farmers, and who have been at the forefront of interventions aimed at ensuring that this vision is soon realized.

Bote Central has three main products (Alamid Coffee, Basilio Coffee, and 18 Days Coffee) that cater to different market segments. While primarily known as a coffee retailer, it is also involved in other stages of the coffee supply chain. To pursue its social mission, Bote Central deals directly with coffee farmers, particularly those based in the uplands. In its web site, Bote Central declares that "farmers need not be just suppliers of quality coffee but should be transformed into community-based coffee social enterprises" (https://botecentral.com/).

In this article, we illustrate how the different challenges faced by the Philippine coffee industry are closely interlinked. Adopting a system thinking perspective, we argue that a holistic and collaborative approach that targets critical points in the coffee supply chain, as demonstrated by the initiatives of Bote Central, can help raise both the productivity and the quality of life of Filipino coffee farmers.

For this study, we posed the following questions: (a) How are the challenges faced by the coffee industry linked with each other? (b) What are the efforts undertaken by Bote Central and other concerned stakeholders to address these interlinked factors as they aim for a more inclusive coffee supply chain? (c) What lessons can be derived by policy makers and by other social enterprises from Bote Central's approach of engaging multiple stakeholders in trying to address a pressing social issue? Our contribution to new knowledge lies in our attempt to utilize systems thinking to make sense of the interaction of players, as well as to illustrate the synergies possible, within the coffee supply chain. 


\section{SYSTEMS DYNAMICS AND INCLUSIVE AGRICULTURAL VALUE CHAINS}

In the systems dynamics methodology, a system (e.g., an ecosystem, a political system, or a mechanical system) is represented as a causal loop diagram, or as a simple map of a system with all its constituent components and their interactions. By capturing these interactions and consequently the feedback loops, a causal loop diagram reveals the structure of the system, and gives insights on how the system might behave over a certain time period (Meadows, 2008). As a result, systems dynamics have been applied in a wide range of areas, including agriculture, business, health care, military science, as well as environmental and economic systems, which usually interact strongly with each other (Currie et al., 2018; Homer \& Hirsch, 2006; Sterman et al., 2013).

Systems dynamics, as applied in governance and management, are a way to encourage holistic thinking among resource allocators and decision makers, allowing them to revisit their mental models. Consequently, they gain qualitative insights into the workings of a system, and the consequences of their decisions. According to Sterman (2001), a holistic worldview allows us to "learn faster and more effectively, identify high leverage points in systems, and avoid policy resistance" (p. 10).

Arguably, adopting a systems perspective is useful in examining the dynamics taking place in agricultural value chains, including that of the coffee industry ${ }^{i}$. This is sorely lacking in many agricultural value chains, where some organizations design and implement interventions that seek to increase agricultural productivity, independent of others who focus on market access, credit access, or capacity building. The overall impact of these interventions, according to Devaux et al. (2018), "has been limited in part by the lack of a more holistic approach that addresses challenges and opportunities all along the value chain" (p. 100).

A useful approach is value chain development (VCD), which is a type of intervention that seeks to address poverty by improving linkages between businesses and poor households within a value chain. This departs from the traditional interventions that focus narrowly on improving the capacity of smallholder farmers to increase their productivity or to better manage natural resources. According to Westlake (2014), value chains for agricultural commodities can function more effectively when smallholder farmers "develop closer relationships with suppliers of inputs and services and with entities that market and process their output" (p.3).

VCD calls for diverse stakeholders to work together to understand how the value chain performs so that they can come up with mutually beneficial options to improve chain performance. According to the ADB (2012), value chain participants, by joining together, "are better able to maintain competitiveness through innovation" (p.vii). Close collaboration among these stakeholders is seen to benefit the poor in terms of better income, access to support services for production, and more secure market linkages. Consequently, wholesalers, processors, and other downstream enterprises also benefit in terms of improved quality and flow of raw materials, reduced transaction costs, and enhanced social and environmental credentials (Devaux et al., 2018).

Conceivably, the use of systems dynamics to complement the VCD perspective will lead to "a more symmetric interaction and equitable distribution of resources, trade-offs and risks among actors in the value chain system" (Hirsch Hadorn et al., 2006; Pagell \& Shevchenko, 2014, as cited 
by Swisher et al., 2017, pp. 2-3). The ultimate goal is to develop agriculture value chains that are 'pro-poor' or 'inclusive' (UNIDO, 2011).

To achieve the above-mentioned goals, it is important for smallholder farmers and farmers' groups not only to adopt modern farming and post-harvest techniques (process upgrading) but also to gain entrepreneurial skills that will enable them to sell value-added products to new markets (product upgrading and functional upgrading). In other words, there is a need to strengthen agricultural innovation capacity among the farmers. However, agricultural innovations can only be stimulated "by the interaction of individual and organizations with diverse - often conflicting - stakes in the management of scarce resources or the governance of productive processes" (Devaux et al., 2018, p. 101). This requires an actor within the value chain to fulfill the role of 'innovation brokering' or 'facilitation' (Klerkx, Hall \& Leeuwis, 2009, p. 413) so as to engender social learning, trust building, and collective action among multiple stakeholders (Devaux et al., 2018).

The role of multi-stakeholder platforms and innovation brokerage in agricultural value chains are emerging areas of inquiry in the literature, with recent works by (Horton, 2012; Yusuf \& Tronsden, 2014; Dror et al., 2016; and Schut et al., 2017). Not surprisingly, "essential knowledge, attitudes, and skills for brokering innovation processes remain scarce" on the field, as existing knowledge in this area have only been recently formalized (Schut et al., 2017, as cited by Devaux et al., 2018).

For this paper, we adopted the above-mentioned premises of value chain development and augmented this with a systems perspective so as to gain additional insight on the interaction of key players within the coffee supply chain. Our case study hopefully sheds some light on how the Philippine coffee supply chain functions, and how efforts of multiple stakeholders can be effectively facilitated to promote agricultural innovation, as well as to ensure sustainable and inclusive value chains.

\section{METHODOLOGY}

Adopting a descriptive research design, we did a single-case (embedded) study that examined the initiatives undertaken by a social enterprise to help upland coffee farmers, within the context of the Philippine coffee supply chain. This is an example of a unique and illustrative case, which, according to Yin (2009), provides a justifiable rationale for a single-case design. Eisenhardt (1989) and Yin (2009) also point out that the case study approach to research reveals a particular event in a real-life context, especially when the boundaries between the phenomenon and context are not clear. Detailed case descriptions, in particular, help explain the dynamics and complexities of an event that could not be captured by experimental or survey research, thus leading to a rich and deep understanding of new phenomena.

To construct the Philippine coffee industry supply chain, we used data collected from the DTI, the Bureau of Plant Industry, the 2017-2020 Philippine Coffee Industry Road Map, and the PCAi Report. For the various efforts undertaken by Bote Central and the PCAi, we gathered data from published reports, feature articles, and video features, as well as from in-depth interviews with Bote Central co-owner Vie Reyes, and her daughter Alyanna Reyes, Business Development Officer of Basilio Coffee. Reyes later referred us to Dennis Rosales, Project Coordinator of Forest Foundation Philippines, one of the partners of Bote Central, when we sought to get more 
information about the efforts being undertaken by stakeholders on the ground. All of our interviews were transcribed so that we could easily examine the narratives that we generated.

Adopting a systems-thinking approach, we generated a system map that graphically shows how the various challenges faced by the Philippine coffee industry are actually interlinked. We then illustrated how the different interventions undertaken by Bote Central touch on specific 'nodes' in the system map. These nodes represent critical points in the coffee supply chain that must be simultaneously and decisively addressed to break the vicious cycles that prevent coffee farmers from adopting modern farm practices and ultimately escaping the poverty trap.

\section{RESULTS AND DISCUSSION}

\subsection{Dissecting the Philippine coffee supply chain}

Figure 1 represents the local coffee supply chain at a glance [Note: In the Philippines, stakeholders use the term 'coffee supply chain' rather than 'coffee value chain']. Just like in other supply chains, several stakeholders are responsible for each set of activities (i.e. input supply, farm production, etc.).

Figure 1: Local coffee supply chain

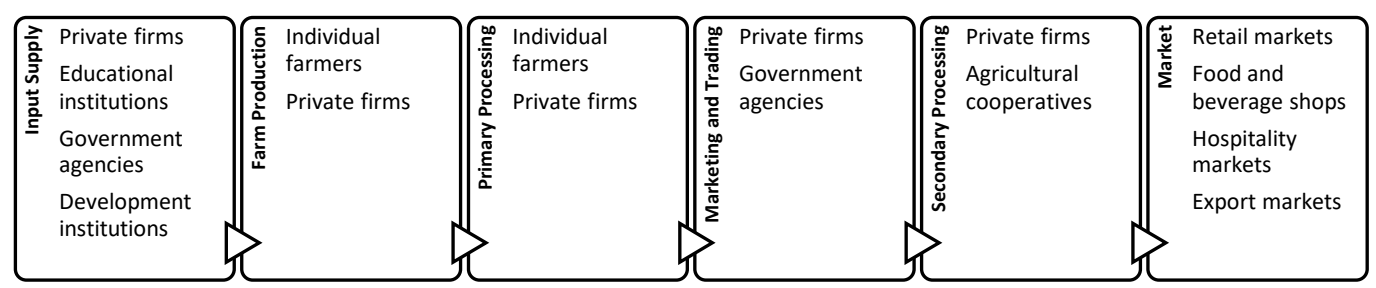

Source: Bureau of Plant Industry (2017)

The chain starts with sourcing of farm inputs and nursery development. Input suppliers refer to licensed dealers or agricultural supply stores that sell inputs to nursery operators and farmers. Transactions in this stage include the selling and purchasing of seeds, planting materials, plastic bags, fertilizer, and farming equipment. Involved in nursery development are private nurseries, nurseries based in state colleges and universities, and commercial farms that produce their own seedlings.

Once the seedlings are ready, these are brought to individual coffee growers or private firms for farm production. This stage involves area selection, land preparation, the transplanting of the seedlings, crop management (i.e., fertilization, pest control, weeding, and pruning), harvesting, sorting, and storage. When harvesting, farmers in most areas use the stripping method (i.e., both red and green beans are stripped from the branch), which results to very poor bean quality.

Once the coffee beans are harvested, they undergo primary processing, during which they are treated for depulping, fermentation, drying, and dehulling. The most common practice for drying 
beans is sun-drying, through which the coffee beans are spread on the ground using mats, nets, or canvasses from two days up to two weeks-depending on the weather.

After undertaking primary processing, coffee farmers sell their coffee beans to traders and agents. Trading takes place at the farms or 'buying stations' of the barangay or of the municipality. The traders would then consolidate the coffee beans and resell these to other traders and processors, such as millers and buying stations of private coffee firms. Processors subsequently convert these coffee beans into roasted coffee beans, roast and ground coffee, specialty coffee, and single-serve coffee mixes.

Finally, these different value-added forms of coffee are handled, transported, and stored for the domestic and export markets. This process involves logistics providers that offer services for transport, storage, and warehousing, and also retail markets, food and beverage shops, hotels and restaurants, and export companies.

The dominant players in the Philippine coffee industry are the coffee manufacturers. Nestle Philippines, Inc., which carries the Nescafe brand, is the largest processor of soluble coffee, accounting for 80-percent of the instant coffee market. Other major companies are Universal Robina Corporation (Great Taste and Blend 45), Commonwealth Foods, Inc. (Café Puro), Century Pacific Group (Kaffe de Oro), Regent Foods Corporation (Koffie), and Goldshine Pharmaceuticals, Inc. (Jimm's).

Aside from the brands produced by the above-mentioned corporations, there are also locally-made ground coffee brands available in the Philippine market. These coffee brands are manufactured by entrepreneurs, mostly operating on a small scale, and are usually named after the place where they are produced (e.g., Café Amadeo, Café de Lipa, Mt. Apo Civet Coffee, Negros Rainforest, Sagada coffee).

Based on the Philippine Statistics Authority (PSA) data, there are nearly 276,000 coffee farms in the Philippines, with about 79.4 million trees, although few of these are commercial scale plantations. The four varieties grown in the country are Robusta, which accounts for $69 \%$ of production, Arabica (24\%), Excelsa (6\%) and Liberica (1\%).

\subsection{Philippine coffee supply chain: Current challenges}

Several sources indicate the lack of supply or declining coffee bean production as a major concern (Philippine Coffee Board, 2018; Crismundo, 2018; Cahiles-Magkilat, 2017). Figure 2 shows that the production of green coffee beans notably declined by an average of 3.51 percent per annum from 52,047 tons in 2006 to 36,171 tons in 2015. Moreover, hectarage and coffee yield declined from 2006 to 2015; while the area for coffee bean plantations declined by an average of 1.02 percent per year from 2006 to 2015 . On the other hand, coffee yield declined by an average of 2.53 percent per year, while the yield per bearing tree decreased by 2.09 percent. These are shown in Figures 3 and 4. 
Figure 2: Green coffee bean production from 2006 to 2015

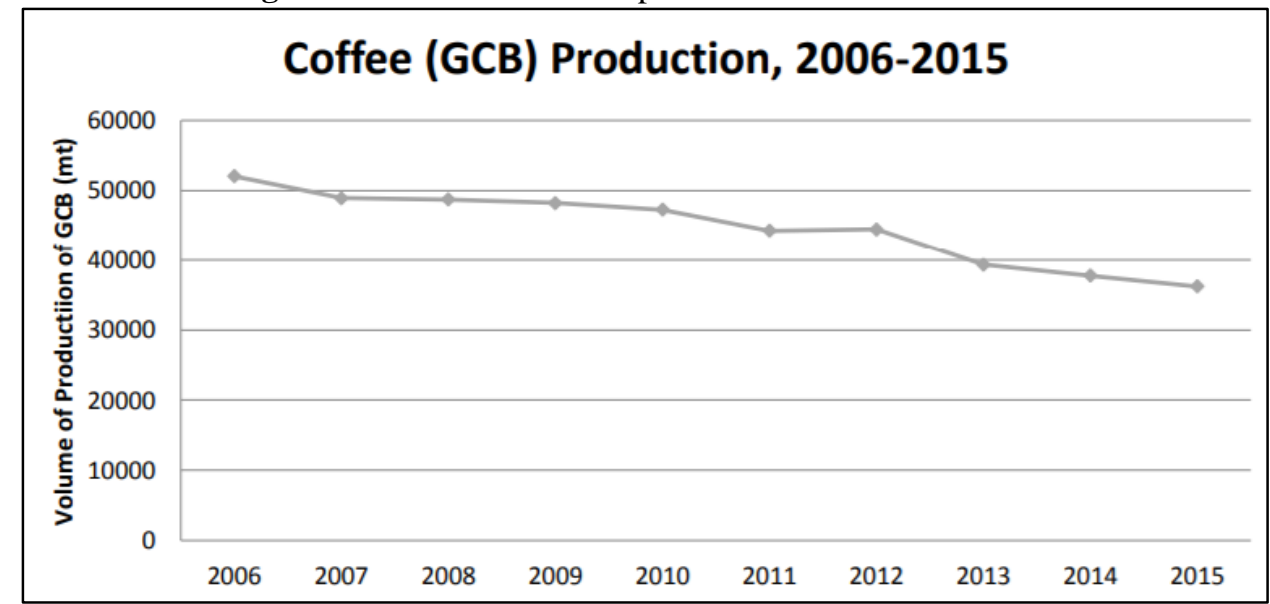

Source: Philippine Statistics Association, as cited in Bureau of Plant Industry (2017)

Figure 3: Area planted and harvested from 2006 to 2015

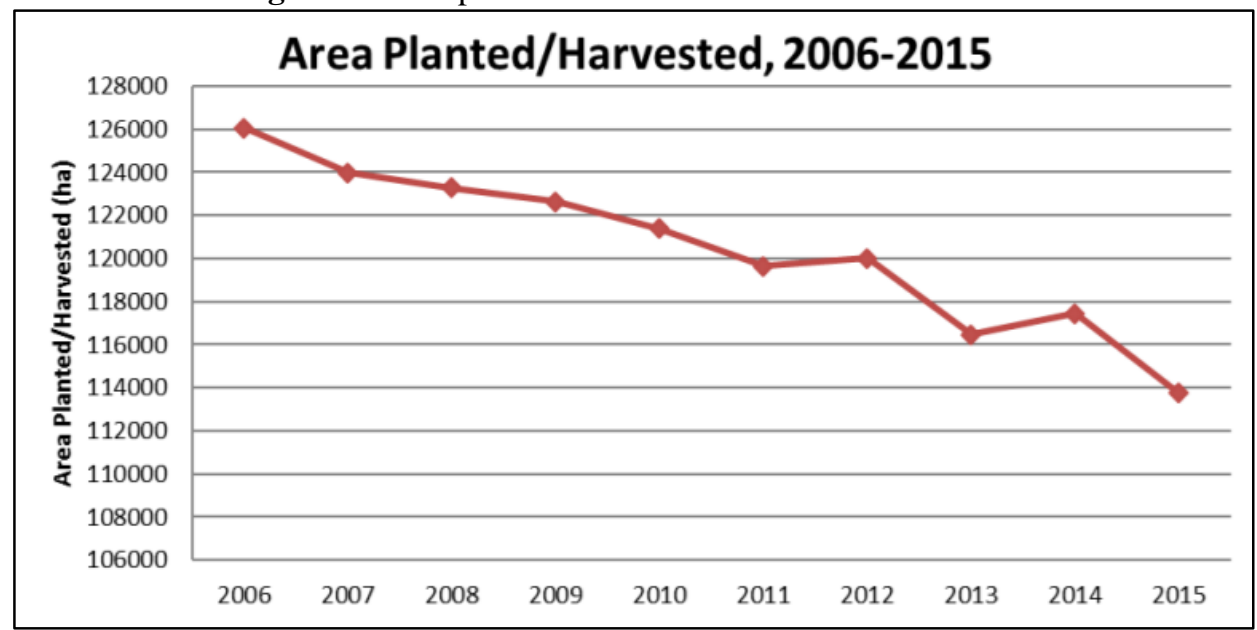

Source: Philippine Statistics Association, as cited in Bureau of Plant Industry (2017) 
Figure 4: Coffee yield levels from 2006 to 2015

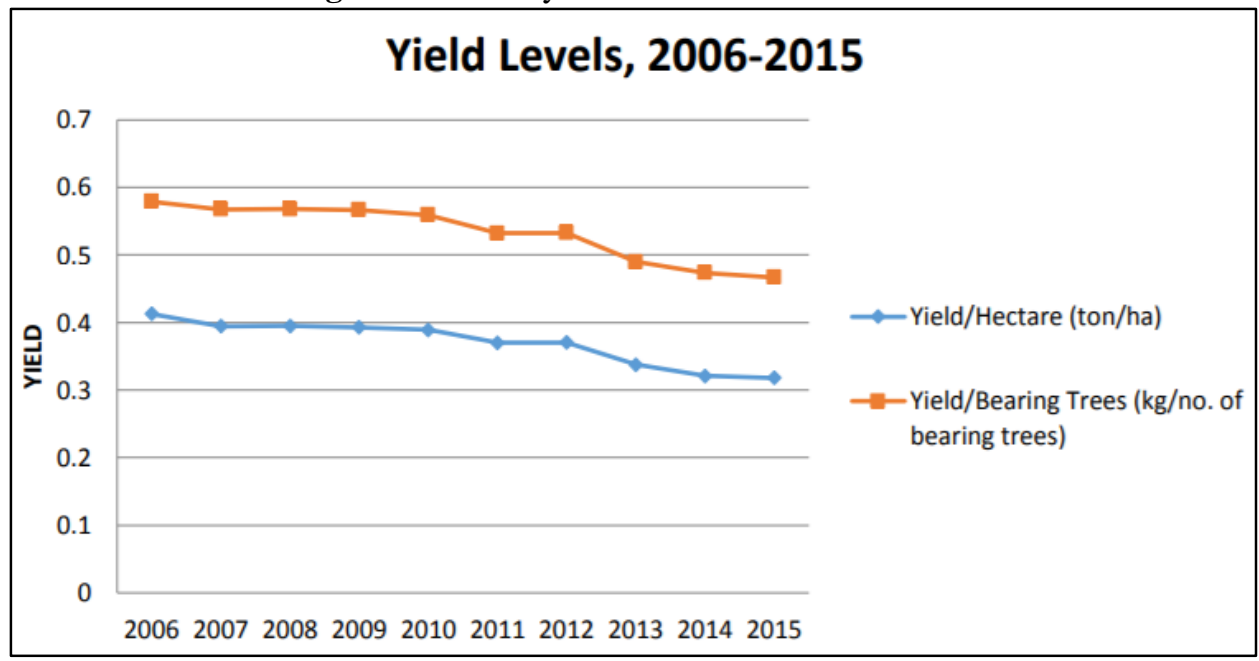

Source: Philippine Statistics Association, as cited in Bureau of Plant Industry (2017)

According to the Philippine Coffee Industry Roadmap for 2017 to 2022, among the contributory factors are 'senile' trees, low soil fertility, limited control of pests and diseases, limited technical skills, lack of post-harvest facilities, and lack of access to credit and markets. A 2017 report by the DTI, on the other hand, attributed it to the following: limited stock of quality seedlings, lack of modern production techniques, crude post-harvest processing methods, lack of coordination among industry stakeholders, gaps in collection and distribution of research and technical knowledge, and popularity of instant coffee.

To determine which stages of the coffee supply chain are beset by these problems, we plotted in Table 1 these contributory factors against the different stages, and saw that most the challenges fall under Input Supply, Farm Production, and Primary Processing, activities that mostly involved coffee farmers.

Table 1: Factors affecting coffee production and yield plotted against stages of coffee supply chain

\begin{tabular}{lcccccc}
\hline \hline Contributing factors* & $\begin{array}{l}\text { Input } \\
\text { supply }\end{array}$ & $\begin{array}{l}\text { Farm } \\
\text { production }\end{array}$ & $\begin{array}{l}\text { Primary } \\
\text { processing }\end{array}$ & $\begin{array}{l}\text { Marketing } \\
\& \text { trading }\end{array}$ & $\begin{array}{l}\text { Secondary } \\
\text { processing }\end{array}$ & Market \\
\hline 'Senile' (old age of) trees & $/$ & & & & & \\
$\begin{array}{l}\text { Low soil fertility } \\
\text { Limited stock of quality }\end{array}$ & $/$ & & & & & \\
seedlings & & & & & & \\
$\begin{array}{l}\text { Limited rejuvenation of } \\
\text { farming lands }\end{array}$ & &, & & & \\
$\begin{array}{l}\text { Limited control of pests } \\
\text { and diseases }\end{array}$ & &, & & & \\
Lack of modern & & & & & \\
production techniques & & & & & & \\
\end{tabular}




\begin{tabular}{|c|c|c|c|c|c|c|}
\hline Contributing factors* & $\begin{array}{l}\text { Input } \\
\text { supply }\end{array}$ & $\begin{array}{l}\text { Farm } \\
\text { production }\end{array}$ & $\begin{array}{l}\text { Primary } \\
\text { processing }\end{array}$ & $\begin{array}{l}\text { Marketing } \\
\& \text { trading }\end{array}$ & $\begin{array}{l}\text { Secondary } \\
\text { processing }\end{array}$ & Market \\
\hline $\begin{array}{l}\text { Very poor farm } \\
\text { management }\end{array}$ & & $/$ & & & & \\
\hline Limited technical skills & & I & I & & & \\
\hline $\begin{array}{l}\text { Crude post-harvest } \\
\text { processing methods }\end{array}$ & & & l & & & \\
\hline $\begin{array}{l}\text { Lack of post-harvest } \\
\text { facilities }\end{array}$ & & & / & & & \\
\hline $\begin{array}{l}\text { Lack of access to credit } \\
\text { and markets }\end{array}$ & & & & / & & \\
\hline $\begin{array}{l}\text { Popularity of instant } \\
\text { coffee }\end{array}$ & & & & & & / \\
\hline $\begin{array}{l}\text { Gaps in collection and } \\
\text { distribution of research } \\
\text { and technical knowledge* }\end{array}$ & & & & & & \\
\hline $\begin{array}{l}\text { Lack of coordination } \\
\text { among industry } \\
\text { stakeholders* }\end{array}$ & & & & & & \\
\hline
\end{tabular}

Notes: * Factors as listed in the 2017-2020 Philippine Coffee Industry Road Map and in the 2017 DTI Report. ** Cannot be placed under a particular stage in the coffee supply chain

At a glance, it might seem obvious that the interventions required should be directed towards the coffee farmers to help them increase their yield, improve their farming practices, and invest in postharvest facilities. This probably explains past and existing government programs that provide fertilizers to farmers, offer training on modern farming techniques, and make available agricultural loans to farmers.

But if the above-mentioned programs have been made available to farmers over the years, then why do the problems persist? Why have production levels and yields continued to decline for over a decade? Specifically, if old trees have to be replaced, then why are farmers not investing in the planting of new trees? If there is a need for post-harvest facilities, then why have farmers not invested in these as well? If the traditional way of farming results in the production of poor-quality beans, then why have farmers not adopted modern farming techniques? Clearly, the problem is more complex than it seems, one that requires a fresh set of lenses to understand, and one that calls for new approaches to solve.

\subsection{Systems map-Interlinked factors revealed}

As the starting point of our analysis of the interventions undertaken by Bote Central and other concerned stakeholders, we created a systems diagram that sought to explain why coffee farmers are poor. Instead of the usual causal loop diagram that identified stocks and flows, we came up with a simplified representation of interrelated causes and effects that is easier for a layman to understand. After presenting the initial results of our study in a research conference, and after showing our original diagram to Bote Central's Vie Reyes for her to validate, we came up with the latest version of the diagram as shown in Figure 5. 
Figure 5: Systems map explaining why coffee farmers are poor (Authors' illustration)

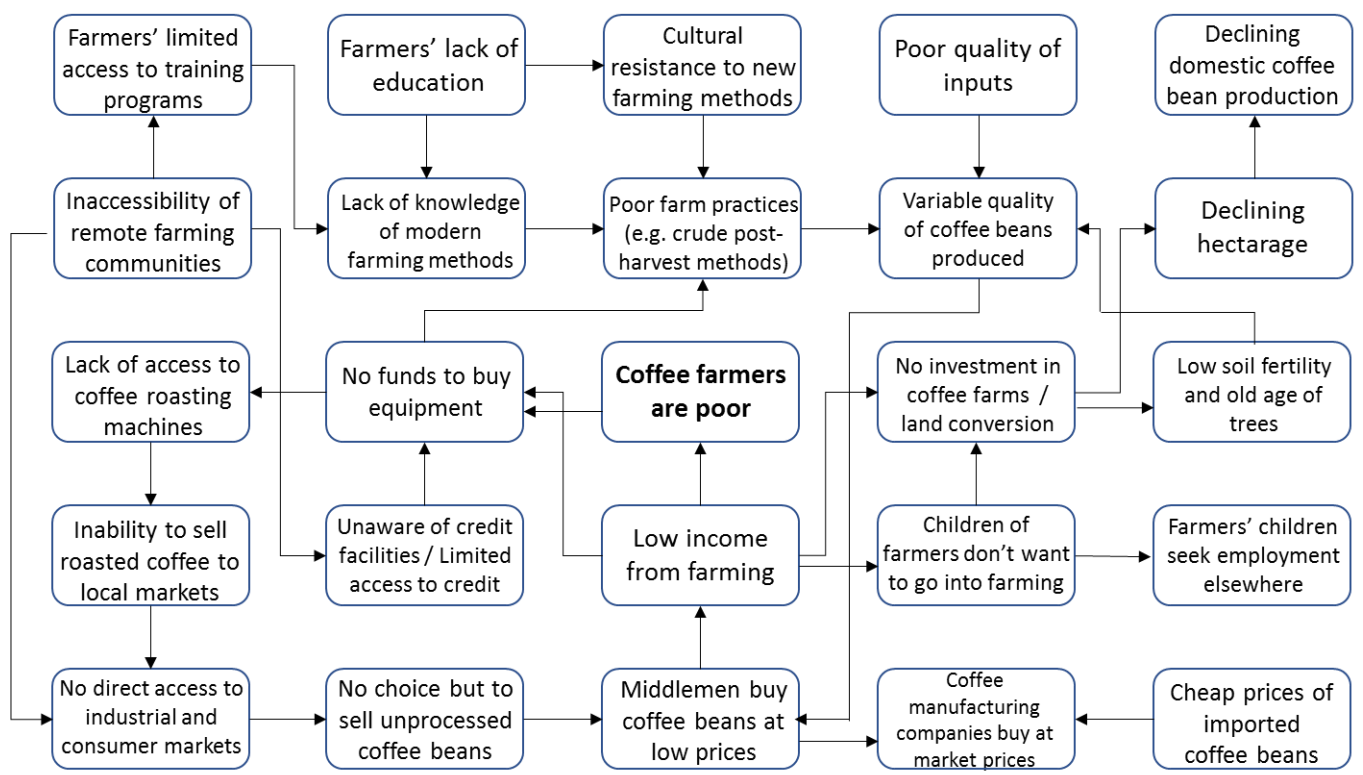

The primary reason that coffee farmers are poor is that they earn very low income from coffee farming. This is because farmers are forced to sell their produce to middlemen at low prices, partly due the variable quality of beans that they produce, and partly due to the farmers' lack of direct access to industrial and consumer markets. Moreover, there is pressure to bring down domestic coffee bean prices because coffee manufacturing companies engaged in secondary processing can easily source imported coffee beans at lower prices.

Accounting for the variable quality of beans produced by coffee farmers are poor quality of inputs, and low soil fertility due to limited rejuvenation of farming lands and overdependence on the use of inorganic fertilizers. Aggravating these are poor farm practices, such as the use of the stripping method and the sun drying method, which affect the quality of the coffee beans after these undergo primary processing.

It does not help that training opportunities offered by the DA and the Municipal Agricultural Office (MAO) do not reach (or are not fully availed of by) the coffee farmers, preventing them from enhancing their farming methods. Also, because of the farmers' low income, they don't have the means to invest in post-harvest facilities that could help them improve the quality of their coffee beans or to further process the coffee beans for consumption in local markets. Thus, they continue to depend on the middlemen, in spite of the low prices that are offered to them. The vicious cycle, therefore, persists.

It is not surprising, therefore, that young people in farming communities refuse to go into farming, leading to the lack of investment in coffee farms, and even to the conversion of farm lands for other purposes; thus, the steady decrease in the total area planted to coffee. 


\subsection{Bote Central-Rationalizing the coffee supply chain}

Bote Central is a social enterprise that aims to "revolutionize to Philippine coffee landscape" (https://botecentral.com/). Sourcing its coffee beans from farmers based in the uplands - many of whom are members of indigenous peoples such as the B'laans and the Mangyans - Bote Central has partner communities in Benguet Province and Mountain Province in Northern Luzon; Mindoro Island in Southern Luzon; and Cotabato in Central Mindanao.

Back in 2007, Basilio and Vie Reyes formulated an ambitious business plan that sought to address the various challenges that plagued the coffee industry in the Philippines. After consulting with various stakeholders, they were repeatedly told how 'complex' and 'impossible' their business plan was. Confident with their vision, the couple set up Bote Central anyway, and eventually proved their cynics wrong.

Helping the upland coffee farmers, however, was not an easy process because in the mid-2000s, the coffee industry, according to Vie, was "messed up". It was easy to blame the usual suspects inefficient practices of local farmers, exploitative middlemen, limited government support, etc. but the Reyes couple recognized the systemic nature of the problem, which led them to the idea of rationalizing the coffee supply chain (Habaradas, 2019).

One of Bote Central's early interventions (done with the help of a management consulting firm) was teaching coffee farmers basic accounting, and teaching them how to use a computer to record their transactions. The farmers, however, were not receptive to the new technology. Learning from this setback, Bote Central shifted its attention to more immediate and more practical concerns. This took the form of assisting the farmers in communicating with the Department of Agriculture (DA), in the proper handling of coffee beans to minimize damage and waste, and in maximizing their earnings from their coffee.

In the meantime, Bote Central continued to buy coffee beans from the farmers at fair-trade prices, including those of less-premium quality, so as to encourage farmers to continue producing even as they gradually improve the quality of their produce. Consequently, Bote Central, had to expand its product line, which included cheaper coffee aimed at a different market segment.

Bote Central established a close relationship with the local farmers, and eventually gained their trust. They were able to do this in Sagada, a municipality in the Mountain Province, because Basilio had previously lived in the community for one year and developed a deep friendship with the locals. As a form of goodwill, Bote Central gave the Sagada farmers a coffee roasting machine, which was meant to provide the locals the ability to roast their own coffee either for domestic consumption or for sale to establishments in the local community. While the locals initially regarded the machine with suspicion, they eventually warmed up to the idea of roasting their own coffee. The Sagada farmers now sell their roasted coffee beans to restaurants in the local and neighboring communities, thus benefitting in terms of increased income (Habaradas, 2019).

Drawing lessons from its experience in Sagada, Bote Central launched in 2007 the Kape't Buhay (Coffee and Life) Program, an incubation program for community-based enterprises. Through this program, coffee farmers received training in coffee agribusiness, were given access to commonservice facilities (e.g. dehuller, solar dryer, depulper, roasting machine, multi-purpose grinder), 
and learned to process and sell the coffee they produce to local communities. For the program to succeed, it was important for the local community to formally organize themselves. In Sagada, this led to the formation of the Mountain Province Association of Coffee Growers.

Showing a viable proof of concept, Bote Central was able to secure a P2-million grant to offer technical assistance for setting up agribusiness systems and training modules for 10 communitybased coffee enterprises (CBCEs). An important feature of Kape't Buhay is the development and establishment of community-based roasting facilities that are run, managed, and operated by farmer clusters and women's groups in collaboration with existing NGOs in strategic target areas (Kape't Buhay, 2012).

Under this program, Bote Central, going through the requisite government procurement procedures, sold its coffee roasting machines to participating communities. It also provided the farmers' groups with basic business training, even as it continued to purchase coffee beans from them. In 2011, the DA funded 10 additional CBCEs through its high-value crop development program. In July 2013, Bote Central turned over Kape't Buhay to the Philippine Coffee Alliance (PCAi), which adopted it as its flagship program. It got additional support from other organizations such as Globe Telecom, Foundation for Sustainable Society, Inc., and the Peace \& Equity Foundation.

Early studies done on community-based coffee enterprises (including those established outside of the Kape't Buhay Program) showed that as of January 2016, 51 CBCEs with 34,221 farming households benefitted from increased coffee margins resulting from activities from production down to distribution. Of the 20 CBCEs developed under the program, 18 are led by women, who occupied key positions in management, operations, and sales (Kape’t Buhay, 2012).

Vie Reyes also revealed that, based on the equipment delivered and serviced by Bote Central as of February 2020, there is a total of 90 facilities, approximately 50-percent of which are run, owned, and managed by farmer cooperatives / associations. About 40-percent are managed and operated by local government units (LGUs), and $10 \%$ by a private enterprise. When asked to what extent farmers' incomes have grown, she said:

For Robusta coffee growers, it is safe to assume a 20- to 25-percent increase of income from the sale of green coffee beans (GCB) alone. From the usual Nestle buying price of PhP80-90 per kilo of Robusta GCB, local roasters are currently buying at PhP95-105 per kilo. Well-processed Arabica, on the other hand, can now command a price of at least PhP300 per kilo of Arabica GCB from the price of PhP60 per kilo way back in 2007, at the onset of the Kape't Buhay Program (email communication, May 3, 2020).

Vie Reyes also mentioned that, aside from better incomes generated, she noticed how the narratives (i.e., needs, wants, complaints, and aspirations) they hear from the farmers have changed from the time Bote Central first interacted with them in 2007. She observed how "indicators such as access to education, food on the table, access to water and electricity, and presence and use of gadgets at home, among others, are visibly apparent." Moreover, the coffee farmers seem to have acquired a fresh mindset about their situation. She said: "I have seen changes in behavior and mindset. Coffee 
farmers nowadays, at least the ones I am in contact with, are more vocal, passionate with coffee, and they willingly participate to learn more because they know they will earn more."

Because of the success of the Kape't Buhay Program, Bote Central and PCAi was approached by Forest Foundation Philippines (FFP) in 2018 to undertake the livelihood component of its comprehensive forest protection and conservation efforts in Mindanao. The groundwork for the planned interventions targeting 14 communities located in Bukidnon and Misamis had already been done.

\subsection{Leverage points identified - Bases for Bote Central's multiple interventions}

Going back to our systems map, we can now determine how the various interventions undertaken by Bote Central address several nodes, which serve as leverage points in breaking the vicious cycle that we earlier identified (see Figure 6).

Figure 6: Leverage points in the systems map and Bote Central's interventions (Authors' illustration)

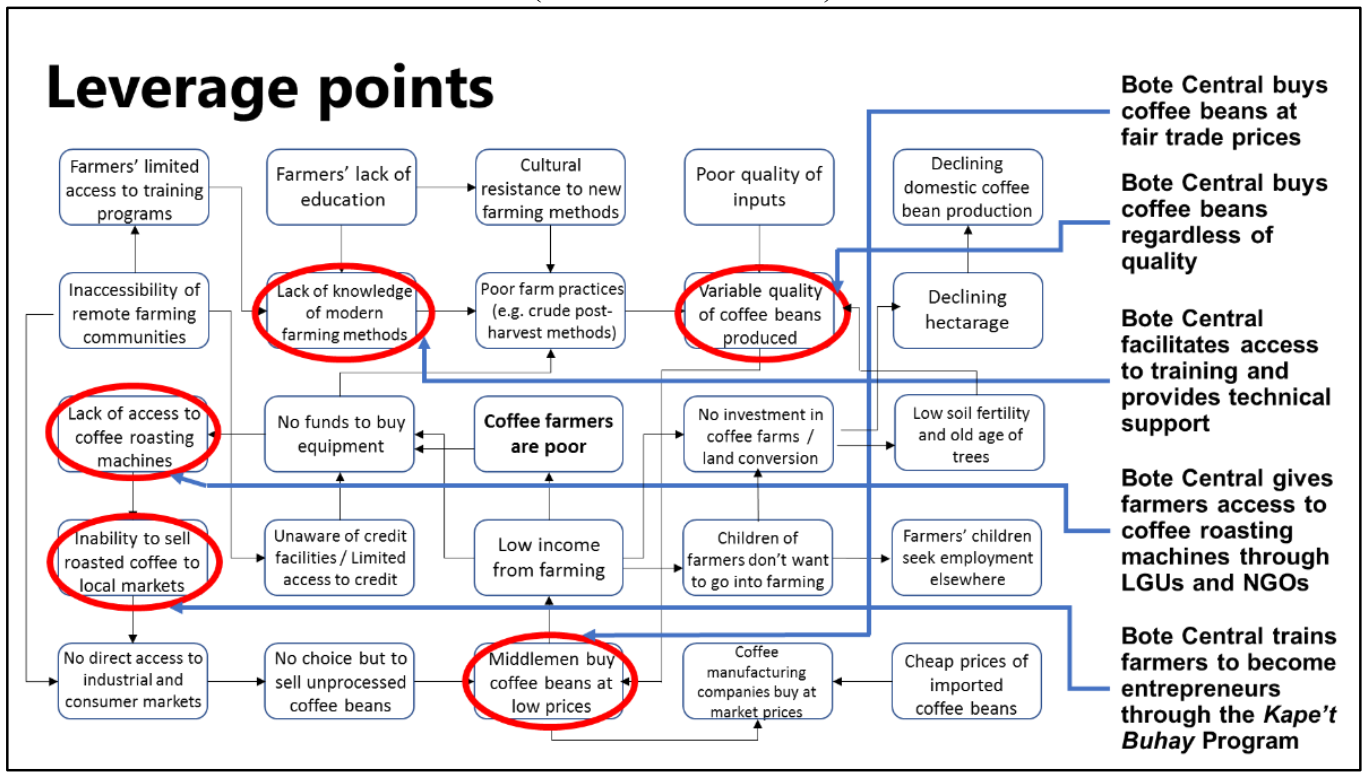

By buying at fair-trade prices, Bote Central has given farming communities from which it sources coffee beans an alternative market for their produce, meaning that they do not have to sell at extremely low prices to middlemen. Bote Central went a step further by buying coffee beans regardless of their quality so as to augment the farmers' income. At the same time, it helped the coffee farmers by linking them up with the DA, which provided them with training to improve their farm practices, including post-harvest techniques. This is meant to ultimately address the low quality of coffee beans produced and sold by the farmers. 
To address the farmers' inability to process their coffee beans into value-added products, Bote Central provided these farming communities access to coffee roasting machines through the LGUs and locally-based NGOs. This enabled farmer clusters and women's groups to set up their CBCEs, which generated added income through the sale of roasted coffee to local and neighboring communities. As the supplier of the coffee roasting machines, Bote Central provided the CBCEs with the technical knowledge and support to operate and maintain these machines, aside from providing them with training on the entrepreneurial aspects of selling coffee through Kape't Buhay.

It is too early to tell whether the initial successes of the Kape't Buhay program will ultimately have an impact on other parts of the system. Will this encourage some members of the next generation to engage in agricultural entrepreneurship? Will this translate to investments aimed at rejuvenating farming lands and the replacement of old trees? Will this stem the tide of land conversions? Will these initial gains ultimately result to the resurgence of the Philippine coffee industry?

What is clear, at this point, is that Bote Central would not have been able to do all of these things without the cooperation of the LGU, especially the municipal agricultural office (MAO), the local NGOs, and the DA. Even its experiment on setting up community-based enterprises could not have been replicated in such a scale without the P2-million grant, which is part of the CSR program of a large international firm.

What seems to have made a difference was the mobilization of all of these resources and expertise through the Kape't Buhay program, under the leadership of Bote Central. This highlights the importance of having a mechanism - a governance model, if you must - that effectively coordinates the efforts of the various players in the coffee supply chain towards a clear and compelling goal. In this case, the leadership role was taken on by a social enterprise that understood the cultural context and the specific needs of their partner communities, that persevered in building trust and social capital with and among community members, that leveraged off the resources of concerned stakeholders, and that tweaked its business model to make its community-based initiatives viable and sustainable.

\section{POLICY IMPLICATIONS}

Formulated back in 2016, the 2017-2020 Philippine Coffee Industry Road Map contains strategies laid down by various stakeholders in government, the private sector, and civil society (including farmers' groups) that are meant to address the limited domestic supply of quality green coffee beans amidst increasing local demand. The road map identified several broad initiatives, such as establishing institutional platforms among different stakeholders, organizing and capacitating coffee farmers, implementing appropriate interventions across the coffee supply chain, making available credit facilities, guarantee funds, and crop insurance for coffee farmers and cooperatives; and providing incentives for coffee farm establishments.

It must be noted that the road map has a long list of key result areas (KRAs), categorized according to specific stages of the coffee supply chain. As shown in Table 2, each one of these KRAs has a prescribed set of performance indicators. The ultimate goal is to increase average yield from 0.30.6 tons per hectare to 1 ton per hectare, and to raise the country's self-sufficiency level from $41.60 \%$ to $160.16 \%$ by 2022 . 
Table 2: Philippine Coffee Road Map - Number of key result areas and performance indicators

\begin{tabular}{lcc}
\hline \hline Stage of supply chain & No. of KRAs & No. of PIs \\
\hline Inputs - Improve quality and availability of planting materials & 2 & 6 \\
Farm production - Enhance farm efficiency and investment & 5 & 8 \\
Processing - Improve competitiveness & 6 & 6 \\
Market - Improve market price and coffee standards & 5 & 6 \\
Support services & 9 & 16 \\
- Financing - access to long-term funds & \\
- Logistics - reduce logistics cost to processors / market & \\
- R\&D - Improve research and extension services & \\
- Policies - Appropriate investment incentives & & \\
- Market intelligence - Reliable industry data & & \\
- Organization - Industry unity in diversity & & \\
\hline TOTAL & & \\
\hline \hline
\end{tabular}

This long list is obviously a result of a desire to accommodate the ideas of various stakeholders involved in the consultation sessions leading to the road map's formulation. On paper, these all look good. After all, who would argue against action plans that attempt to fill existing gaps, such as the use of improved / registered coffee planting materials; adoption of the good agricultural practices (GAP) of coffee; initial provision / subsidy of farm inputs and appropriate post-harvest facilities; access to credit and market outlets of coffee growers, and continuing education programs for coffee growers?

However, there is a danger in believing that assigning the action programs under each of these KRAs to the responsible government agency or working group will automatically generate the desired outcomes. Without an appropriate governance model in place, these action programs are likely to be implemented in a fragmented manner, and will not generate the synergies of a holistic approach directed towards addressing the unique and specific needs of different coffee growing communities across the country.

Tasked to monitor the implementation of the coffee road map is the Philippine Coffee Council (PCC), a private-sector led body that is supposed to receive government support from the national level down to the regional and provincial levels. It was left to this council to define and clarify the levels of engagement of stakeholders that "play critical roles in the successful execution" of the road map.

\subsection{Recommendations}

Drawing insights from the experience of Bote Central and of other cross-sector partnerships that have scaled up initiatives to address problems at the community level (Austin, 2000; Habaradas, 2016), we suggest that the PCC deputize the provincial coffee councils to come up with their own plans based on the realities of their geographic area. This is because coffee growers in different communities belong to different supply chains, have varying costs of production depending on their access to inputs, and deal with various intermediaries that cater to different institutional and consumer markets. Different communities also have varying levels of sophistication with regards to their farming and post-harvest practices, and will not necessarily be receptive to training and other interventions introduced by outsiders. 
The above-mentioned conditions drive home the importance of getting the buy-in of the community members themselves before any of the action plans mentioned in the road map can be introduced. This is where the LGUs and NGOs can come in, since they are the ones that are most familiar with the socio-economic and cultural context of these communities.

Once an entry point has been established in the community, it is essential for a key player in the local coffee supply chain to assume the leadership / facilitator role so that various efforts meant to help the coffee growers in the area are coordinated and sustained. Conceivably, the leadership role can be assumed by any of the following: (a) the Provincial Government, which has the resources and the political clout to ensure action among government agencies under its authority; (b) a vertically-integrated business organization that has the economic resources that can be mobilized at different stages of the supply chain; (c) a reputable academic institution based in the region that can mobilize its wide network of alumni, donors, and partner organizations to support the local coffee industry; or (d) a corporate foundation or a non-government organization that has the resources to fund its advocacy, and that can utilize its valuable expertise in community organizing.

\subsection{Another potential governance model?}

A candidate for this leadership role is the Forest Foundation Philippines (FFP), which has entered into a partnership with Bote Central, through the PCAi. FFP is a non-profit organization that provides support to individuals or groups engaged in forest protection and conservation. Working with other NGOs, people's organizations, government, and academe, it seeks to protect the forests in the Sierra Madre from Cagayan down to Quezon Province, and also in Palawan, Samar, Leyte, Bukidnon, and Misamis.

According to FFP Project Coordinator Dennis Rosales, the foundation realized that "in order for us to embed in the minds of forest-dependent communities the importance of conserving our forests, it is necessary to address their basic needs first by providing them with sustainable livelihood" (personal communication, February 12, 2020). FFP brought in Bote Central and PCAi because it wanted to introduce the livelihood component to ensure the sustainability of its forest conservation efforts. Planting coffee trees is seen as a way to conserve the forests and to promote biodiversity because coffee trees can co-exist with indigenous trees in the forest. "The goal of the partnership," Rosales said, "is to address the twin issues of poverty and environmental degradation, while setting up a social enterprise that would somehow impact the forest communities in the area" (personal communication, February 12, 2020).

FFP initially provided a grant for the PCAi to conduct an assessment of 14 communities in Bukidnon and Misamis to determine whether they are ready and willing to participate in PCAi's coffee entrepreneurship program. PCAi undertook the consultation sessions and focus group discussions (FGDs) in the target communities with the help of FFP's existing partner organizations, such as the Sandani Institute, the Xavier Science Foundation, and the Kitanglad Volunteers Association, Inc., who were already undertaking other FFP-funded projects in the area.

FFP has since provided Bote Central and PCAi a three-year grant (starting January 2019), which aims to capacitate the coffee farmers, using the Kape't Buhay model, and to strengthen the PCAi network in the area. But this requires several other activities that include getting the prior and 
informed consent of the communities, which is necessary when dealing with indigenous people's (IP) communities; conducting a baseline survey of the physical characteristics and of the socioeconomic status of the areas covered so that these can be aligned with the interventions that will be implemented; and mobilizing the "coffee doctors" or technical experts based in the region, who will serve as mentors of the farming communities in the next two years.

The point of this illustration is to show that FFP has what it takes to assume the leadership role in the coffee supply chain within which the Bukidnon and Misamis coffee growers are embedded. This is because FFP has the resources to fund the interventions needed, the power to hold the recipients of its grants accountable for results, and a network of existing partners undertaking various projects under its auspices, whose expertise it can leverage for other related projects. In short, it has built social capital due to its presence in (and contributions to) the area over the years. These are the same elements that enabled Bote Central to make positive inroads in its own partner communities.

We recognize, though, that FFP, as a funding institution, will not be able to fulfill this role on a permanent basis, as it is expected to exit once the goals of the programs it supports have been met. This is where the PCAi, currently a program partner, can take over. PCAi, which is envisioned to be run, managed, and operated by farmer leaders and industry allies, would have established a stronger presence in the areas within which they operate, and could eventually assume the leadership role.

\subsection{A pathway to entrepreneurial and empowered coffee communities (PEECCs)}

The experience of Bote Central in its original partner communities and the emerging model led by FFP in Bukidnon and Misamis seem to indicate a viable pathway for achieving an inclusive coffee supply chain, something that could be applied to supply chains of other agricultural crops.

This proposed Pathway to Entrepreneurial and Empowered Coffee Communities (PEECCs) can supplement the 2017-2020 Philippine Coffee Industry Road Map, as it brings to the fore the underlying mechanisms that can enhance the efficacy of the action plans listed in the road map. This involves the following: (a) establishing entry in the target community and getting the community members' buy-in; (b) taking stock of the physical characteristics of the area and the socio-cultural and economic conditions of the community, which will serve as baseline data; (c) providing a stable source of income for the community members, even as other interventions are being implemented; (d) tapping the services of the LGU or a local NGO to help manage, at the onset, common service facilities, which can eventually be turned over to the local cooperative or farmers' group; (e) providing entrepreneurial training and mentorship to enhance the ability of farmers' groups to undertake higher value-adding activities in the coffee supply chain; (f) convening a group of concerned stakeholders in the area (e.g. regional or provincial coffee council); and (g) identifying an organization that will take on the leadership role in coordinating the efforts of the various stakeholder groups, until the time the farmers' groups have become truly entrepreneurial and empowered coffee communities. 


\section{IMPLICATIONS FOR GENERAL PRACTICE}

Our study has shown that value chain analysis can be utilized to address more than just economic objectives such as reducing cost, increasing productivity, and creating value for end-consumers. Using a more holistic lens that incorporates social objectives, such as improving the plight of coffee farmers previously marginalized in an exploitative value chain set-up, it can generate valuable insights especially when combined with a systems perspective that considers the dynamics inherent in structures that involve multiple stakeholders with often contrasting goals. Conceivably, the same approach can be adopted to examine other agricultural supply chains, given their unique contexts. It is hoped that policymakers, government agencies, business leaders, civil society, and farmers' groups, by adopting a holistic and multi-stakeholder approach, will be able to make substantial inroads in creating inclusive agricultural value chains, especially in the developing world.

\section{REFERENCES}

Asian Development Bank. (ADB) (2012). Evaluation knowledge study - Support for agricultural value chain development. Asian Development Bank.

Austin, J. (2000). The collaboration challenge: How nonprofits and businesses succeed through strategic alliances. San Francisco: Jossey-Bass.

Bureau of Plant Industry. (2017). 2017-2022 Philippine Coffee Industry Roadmap. http://bpi.da.gov.ph

Cahiles-Magkilat, B. (2017, September 25). DTI seeks to address supply chain gap in coffee industry. Manila Bulletin. https://business.mb.com.ph

Crismundo, K. (2018). Industry road map to boost production of PH coffee. https://www.pna.gov.ph/articles/1032353

Currie, D., Smith, C., \& Jagals, P. (2018). The application of system dynamics modelling to environmental health decision-making and policy - A scoping review, BMC Public Health, 18, 402.

Department of Trade and Industry. (DTI) (2017). The Philippines in the coffee global value chain. http://industry.gov.ph/ wp-content/ uploads/2017/11/DTI-Policy-Brief-2017-10-ThePhilippines-in-the-Coffee-Global-Value-Chain.pdf

Department of Trade and Industry. (DTI) (2018). Coffee value chain analysis and upgrading in R8. https://www.dti.gov.ph

Devaux, A., Torero, M., Donovan, J. \& Horton, D. (2018). Agricultural innovation and inclusive value-chain development: A review, Journal of Agribusiness and Developing and Emerging Economies, 8(1), 99-123.

Dror, I., Cadilhon, J., Schut, M., Misiko, M. \& Maheshwari, S. (2016). Innovation platforms for agricultural development: Evaluating the mature innovation platforms landscape. Routledge, London and New York, NY.

Eisenhardt, K. (1989). Building theories from case research. Academy of Management Review, 14(4), 532-550.

Habaradas, R. (2016). Social innovation in the Philippines: Pursuing SDGs through cross-sector partnerships. Asia-Pacific Tech Monitor, 33(3), 45-48. http://techmonitor.net/tm/images/9/96/16jul_sep_sf4.pdf 
Habaradas, R. (2019). Innovative business models of social enterprises in the Philippines. Asia Research Policy, 18(2), 71-80. Korea Institute of S\&T Evaluation and Planning (KISTEP).

Homer, J., \& Hirsch, G. (2006). System dynamics modeling for public health: Background and opportunities, American Journal of Public Health, 96(3), 452-458.

Horton, D. (2012). Organizational change for learning and innovation. Agricultural Innovation Systems: An Investment Sourcebook. Washington: The World Bank.

Klerkx, L., Hall, A. \& Leeuwis, C. (2009). Strengthening agricultural innovation capacity: are innovation brokers the answer?. International Journal of Agricultural Resources, Governance and Ecology, 8(5/6), 409-438.

Meadows, D. (2008). Thinking in systems: A primer. Earthscan.

Philippine Coffee Board. (2018). Trading coffee. https://philcoffeeboard.com/ trading-coffee/

Schut, M., Andersson, J., Dror, I., Kamanda, J., Sartas, M., Mur, R., Kassam, S., Brouwer, H., Stoian, D., Devaux, A., Velasco, C., Gramzow, A., Dubois, T., Flor, R.J., Gummert, M., Buizer, D.,McDougall, C., Davis, K., Homann-Kee Tui, S. \& Lundy, M. (2017). Innovation platforms in agricultural research for development: Guidelines for research, development, and funding agencies on how to design, budget, and implement successful innovation platforms. International Institute of Tropical Agriculture and Wageningen University.

Sterman, J. (2001). System dynamics modeling: Tools for learning in a complex world. California Management Review, 43(4), 8-25.

Sterman, J., Fiddaman, T., Frank, T., Jones, A., McCauley, S., Rice, P., Sawin, E., Siegel, L. (2013). Management flight simulators to support climate negotiations. Environmental Modelling \& Software, 44, 122-135.

Swisher, M., Ruiz-Menjivar J., \& Koenig, R. (2017). Value chains in renewable and sustainable food systems, Renewable Agriculture and Food Systems, 33(1), 1-5.

United Nations Industrial Development Organization. (UNIDO) (2011). Pro-Poor Value Chain Development: 25 Guiding Questions for Designing and Implementing Agroindustry Projects. United Nations Industrial Development Organization, Vienna.

Westlake, M. (2014). Developing sustainable, green and inclusive agricultural value chains in the Caribbean and the Pacific Islands. CTA and the UN Food and Agriculture Organization.

Yin, R. (2009). Case study research: design and methods ( $4^{\text {th }}$ ed.). Thousand Oaks, California: Sage Publications.

Yusuf, M. \& Trondsen, T. (2014). Competitive forces and innovation strategies: a study of the Indonesian crab industries, Journal of Agribusiness in Developing and Emerging Economies, 4(1), 78-96.

\footnotetext{
i According to the Asian Development Bank (2012), "a value chain is not identical to a supply chain. A value chain is about linkages generating value for the consumer. A supply chain is about processes of moving and transforming commodities into products from producers to consumers. While a value chain is about generating value for the consumer, a supply chain is about logistics." For our paper, though, we use these terms interchangeably, since stakeholders of the Philippine coffee industry use the term supply chain, even as the literature utilizes the term value chain.
} 